\title{
PENGEMBANGAN LEMBAR KERJA PESERA DIDIK BERBASIS EMANCIPATORY QUESTION UNTUK SISWA KELAS XI SMA
}

\author{
Nadila, Abd Haris Nasution, Yuni Artha Simanjuntak \\ Fakultas Ilmu Sosial Universitas Negeri Medan, Nadilla156@gmail.com
}

\begin{abstract}
ABSTRAK
Penelitian ini bertujuan untuk mengembangkan produk berupa lembar kerja peserta didik berbasis emancipatory question untuk siswa kelas XI SMA berdasarkan penilaian ahli materi, ahli media dan ahli evaluasi pembelajaran sejarah serta penilaian guru juga siswa. Dalam pelaksanaannya penelitian ini menggunakan metode penelitian dan pengembangan (R\&D) model Borg and Gall. Prosedur pengembangan yang digunakan pada penelitian ini meliputi 9 (sembilan) tahapan yaitu : (1) tahap potensi dan masalah, (2) pengumpulan data, (3) desain produk, (4) validasi desain, (5) revisi desain, (6) uji coba produk, (7) revisi produk, (8) uji coba pemakaian, dan (9) revisi produk. Subjek dalam penelitian ini terdiri dari 3 (tiga) siswa kelas XI MIA ${ }^{2}$ untuk uji coba kelompok kecil, 6 (enam) siswa kelas XI MIA ${ }^{1}$ untuk uji coba kelompok sedang, dan 30 siswa kelas XI IIS ${ }^{1}$ untuk uji coba kelompok besar di SMA Swasta Cerdas Murni. Metode yang digunakan untuk menganalisis data adalah dengan teknik deskriptif kualitatif yang diungkapkan dalam distribusi skor dan kategori skala penilaian. Hasil penelitian dan pengembangan ini menunjukkan bahwa produk yang dikembangkan berupa lembar kerja peserta didik memenuhi validasi oleh ahli materi sejarah mencapai 84,6\% dengan kategori sangat valid, ahli media pembelajaran sejarah mencapai $90 \%$ dengan kategori sangat valid, ahli evaluasi pembelajaran sejarah mencapai $90 \%$ dengan kategori sangat valid, oleh guru pelajaran sejarah mencapai $90 \%$ dengan kategori sangat valid dan melihat respon siswa pada uji coba produk (kelompok besar) mencapai 89 dengan kategori sangat valid/sangat layak diguankan. Implikasi dari hasil penelitian ini adalah diperoleh kelayakan lembar kerja peserta didik berbasis emancipatory question untuk digunakan sebagai alat evaluasi pembelajaran sejarah.
\end{abstract}

Kata Kunci : LKPD, emancipatory question.

\section{PENDAHULUAN}

Hasil survei menyatakan bahwa sejarah menempati urutan ke-tiga dalam daftar pelajaran yang tidak disukai siswa (Education, 2014). Hal ini disebabkan karena banyak yang berpikiran bahwa sejarah adalah pelajaran menghapal tanggal dan nama belaka (Matasari, 2016). Padahal sejarah adalah pelajaran yang sangat 
penting karena materinya mengandung makna positif yang mampu mengembangkan integritas dan jati diri siswa, sehingga terbentuk karakter siswa yang memiliki sikap nasionalisme, toleransi, empati dan sikap-sikap positif lainnya yang berharga bagi diri dan lingkungan masyarakat. Oleh karena itu kreativitas perlu dikembangkan oleh guru sejarah melalui penciptaan suasana belajar di kelas yang dapat mendorong siswa mengaktualisasikan diri. Siswa perlu diberikan kesempatan untuk belajar dengan daya intelektualnya sendiri melalui proses stimulus lewat pertanyaan-pertanyaan maupun penugasan, sehingga siswa dapat melihat suatu hal dari berbagai sudut pandang dan menemukan alternatif dalam menyelesaikan masalah yang dihadapi. Hal ini bertujuan agar siswa dapat mencapai indikator pelajaran yang telah ditetapkan. Untuk melihat ketercapaian tersebut guru dapat melakukan evaluasi pembelajaran melalui Lembar Kerja Peserta Didik (LKPD). Namun, pertanyaan yang terdapat pada Lembar Kerja Peserta Didik (LKPD) saat ini hanya bersifat teknis yang menuntut jawaban tentang apa, siapa, kapan dan dimana. Akibatnya muncul anggapan keliru bahwa sejarah hanya pelajaran menghapal saja (Hasan, 2012: 8).

Dari hasil observasi dan wawancara penelitian yang dilakukan di SMA Cerdas Murni menunjukkan bahwa pertanyaan yang ada pada Lembar Kerja Peserta Didik (LKPD) mata pelajaran sejarah hanya bersifat teknis, desain tampilannya tidak menarik karena menggunakan kertas buram dan jarak antar huruf terlalu rapat sehingga mengurangi konsentrasi siswa saat membaca. Selain itu substansi Lembar Kerja Peserta Didik (LKPD) juga tidak mendukung siswa untuk memenuhi indikator capaian belajar. Keadaan ini menjadikan Lembar Kerja Peserta Didik (LKPD) tersebut tidak layak dijadikan sebagai alat evaluasi. Padahal evaluasi sangat penting dilakukan oleh guru untuk menilai keberhasilan pembelajaran, sesuai dengan Pasal 1 UU No.14 Tahun 2015 Tentang Guru dan Dosen menyatakan bahwa guru adalah pendidik profesional dengan tugas utama mendidik, mengajar, membimbing, mengarahkan, melatih, menilai dan mengevaluasi peserta didik dalam pembelajaran.

Melihat Lembar Kerja Peserta Didik (LKPD) yang digunakan saat ini tidak memenuhi substansi maka diperlukan model pertanyaan Emancipatory 
questionuntuk memfasilitasi peserta didik berpikir kritis, pemberdayaan dan emansipasi sekaligus juga memproduksi pengetahuan melalui proses pembelajaran dikelas (Supriatna, 2007: 8). Melalui model pertanyaan Emancipatory question ini, pembelajaran sejarah dapat lebih menarik dan disukai oleh siswa, karena dapat menjadi sarana penghubung masa lalu dan masa kini.Emancipatory questiondifokuskan pada isu-isu mengenai pengaruh kuasaterhadap apa yang terjadi dan bagaimana orang-orang melakukan interpretasi danpenjelasan mengenai apa yang terjadi dan kemudian bertanya mengapa sesuatu harus terjadi (Donald dalam Supriatna, $2007: 7)$.

Untuk mengatasi permasalahan Lembar Kerja Peserta Didik (LKPD) yang tidak sesuai dengan syarat penyusunan, maka perlu dilakukan pengembangan terhadap Lembar Kerja Peserta Didik (LKPD) sejarah yang menarik dan disukai oleh siswa serta dapat digunakan oleh guru sebagai alat evaluasi pembelajaran. Oleh karena itu, peneliti tertarik untuk melakukan penelitian ini dengan judul "Pengembangan Lembar Kerja Peserta Didik Berbasis Emancipatory Question Untuk Kelas XI SMA"

Berdasarkan uraian masalah diatas, identifikasi masalah dan batasan masalah penelitian diatas maka rumusan penelitian ini adalah Bagaimana mengembangkan Lembar Kerja Peserta Didik berbasis Emancipatory Question untuk siswa kelas XI SMA berdasarkan penilaian ahli materi, ahli media dan ahli evaluasi pembelajaran sejarah serta penilaian guru juga siswa.

\section{METODE DAN FOKUS PENELITIAN}

Penelitian ini menggunakan metode penelitian dan pengembangan atau Research and Development (R\&D) model Borg and Gall. Terdapat 10 (sepuluh) tahap yaitu (1) potensi dan masalah, (2) pengumpulan data, (3) desain isi, (4) validasi desain produk, (5) revisi desain produk, (6) uji coba produk, (7) revisi produk, (8) uji coba pemakaian, (9) revisi akhir, (10) produksi massal. Namun pada penelitian ini karena beberapa pertimbangan baik secara waktu dan biaya maka penelitian dan pengembangan lembar kerja peserta didik berbasis emancipatory question untuk siswa kelas XI SMA ini hanya sampai pada tahap ke-9 (sembilan). 


\section{HASIL DAN PEMBAHASAN}

Hasil penelitian dan pembahasan dalam penelitian ini berupa deskripsi mengenai Pengembangan Lembar Kerja Peserta Didik Berbasis Emancipatory Question Untuk Siswa Kelas XI SMA. Penelitian dan pengembangan ini telah sesuai dengan prosedur Research and Development $(R \& D)$ model borg and gall. Terdapat 10 (sepuluh) tahap yaitu (1) potensi dan masalah, (2) pengumpulan data, (3) desain isi, (4) validasi desain produk, (5) revisi desain produk, (6) uji coba produk, (7) revisi produk, (8) uji coba pemakaian, (9) revisi akhir, (10) produksi massal. Namun pada penelitian ini karena beberapa pertimbangan baik secara waktu dan biaya maka penelitian dan pengembangan lembar kerja peserta didik berbasis emancipatory question untuk siswa kelas XI SMA ini hanya sampai pada tahap ke-9 (sembilan). Berikut ini adalah deskripsi pembahasan hasil penelitian tersebut.

\section{A. Penilaian Validator}

Dari hasil validasi oleh ahli materi diketahui bahwa produk yang dikembangkan berupa lembar kerja peserta didik (LKPD) berbasis emancipatory question mendapatkan kualifikasi "valid" dengan persentase 75\%. Pada penilaian oleh ahli materi ini terdiri dari 4 kriteria penilaian diantaranya aspek isi, aspek penyajian, aspek tampilan, dan aspek kebahasaan. Namun melihat respon validator, produk berupa lembar kerja peserta didik (LKPD) berbasis emancipatory question yang dikembangkan harus direvisi sesuai dengan saran yang diberikan. Setelah dilakukan revisi, produk kembali dinilai oleh ahli materi. Dari hasil revisi tersebut diketahui bahwa produk tersebut mendapatkan kualifikasi "sangat valid" dengan persentase $88 \%$. Tingkat kevalidan dan kelayakan lembar kerja peserta didik (LKPD) berbasis emancipatory questionmenurut ahli materi jika disajikan dalam bentuk diagram batang adalah sebagai berikut :

\section{Gambar 1.1. Persentase Uji Kelayakan dan Kevalidan Produk Berdasarkan} Penilaian Ahli Materi 


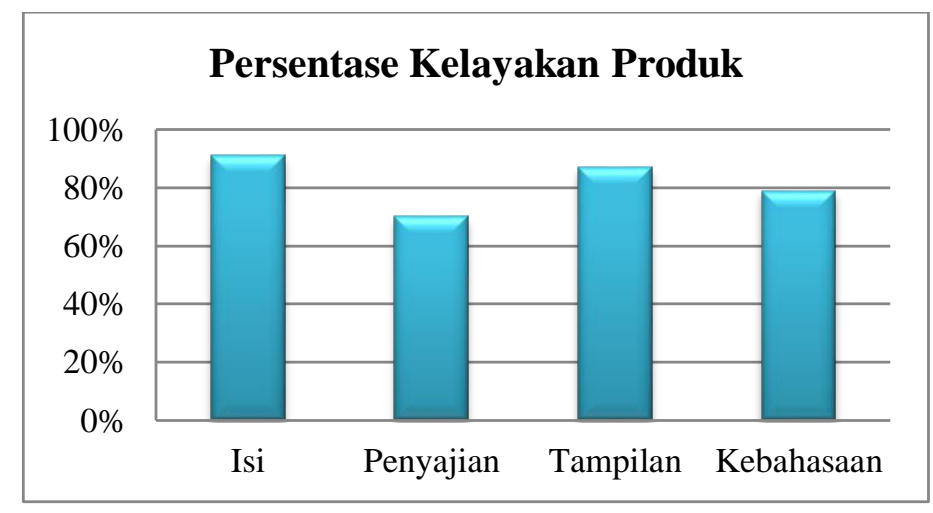

Kedua, dari hasil validasi oleh ahli media diketahui bahwa produk yang dikembangkan berupa lembar kerja peserta didik (LKPD) berbasis emancipatory question mendapatkan kualifikasi "valid" dengan persentase 79\%. Pada penilaian oleh ahli media ini terdiri dari 4 kriteria penilaian diantaranya aspek bahasa, aspek penyajian, aspek efek media terhadap kegiatan belajar, dan aspek tampilan. Namun melihat respon validator, produk berupa lembar kerja peserta didik (LKPD) berbasis emancipatory question yang dikembangkan harus direvisi sesuai dengan saran yang diberikan. Setelah dilakukan revisi, produk kembali dinilai oleh ahli media. Dari hasil revisi tersebut diketahui bahwa produk tersebut mendapatkan kualifikasi "sangat valid" dengan persentase 90\% . Tingkat kevalidan dan kelayakan lembar kerja peserta didik (LKPD) berbasis emancipatory question menurut ahli media jika disajikan dalam bentuk diagram batang adalah sebagai berikut :

Gambar 1.2. Persentase Uji Kelayakan dan Kevalidan Produk Berdasarkan Penilaian Ahli Media

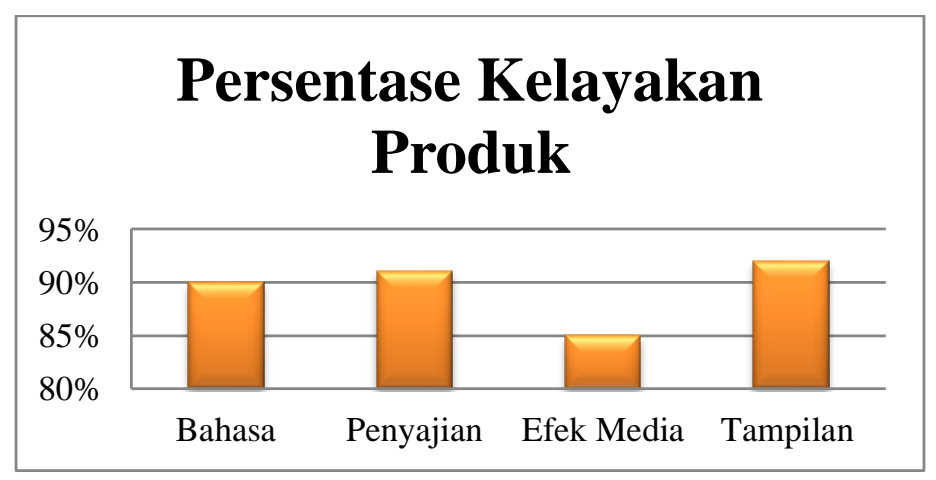


Ketiga, dari hasil validasi oleh ahli evaluasi diketahui bahwa produk yang dikembangkan berupa lembar kerja peserta didik (LKPD) berbasis emancipatory question mendapatkan kualifikasi "valid" dengan persentase $75 \%$. Pada penilaian oleh ahli evaluasi ini terdiri dari 3 kriteria penilaian diantaranya aspek isi, aspek kesesuaian soal dengan KI, KD, dan indikator, serta aspek bentuk soal. Namun melihat respon validator, produk berupa lembar kerja peserta didik (LKPD) berbasis emancipatory question yang dikembangkan harus direvisi sesuai dengan saran yang diberikan. Setelah dilakukan revisi, produk kembali dinilai oleh ahli evaluasi. Dari hasil revisi tersebut diketahui bahwa produk tersebut mendapatkan kualifikasi "sangat valid" dengan persentase 90\% . Tingkat kevalidan dan kelayakan lembar kerja peserta didik (LKPD) berbasis emancipatory questionmenurut ahli evaluasi jika disajikan dalam bentuk diagram batang adalah sebagai berikut :

Gambar 1.3. Persentase Uji Kelayakan dan Kevalidan Produk Berdasarkan Penilaian Ahli Evaluasi

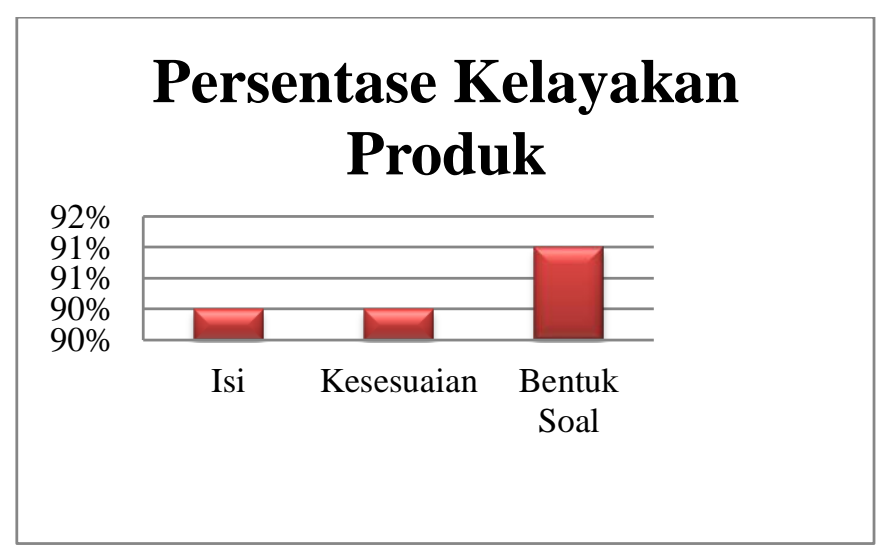

Keempat, adalah hasil validasi oleh Guru sejarah. Pada penilaian oleh Guru sejarah ini terdiri dari 3 kriteria penilaian diantaranya aspek isi, aspek tampilan, dan aspek kebahasaan. Dari hasil penialain tersebut diketahui bahwa produk yang dikembangkan berupa lembar kerja peserta didik (LKPD) berbasis emancipatory question mendapatkan kualifikasi "sangat valid" dengan persentase 90\%. Tingkat kevalidan dan kelayakan lembar kerja peserta didik (LKPD) berbasis emancipatory questionmenurut ahli materi jika disajikan dalam bentuk diagram batang adalah sebagai berikut : 


\section{Gambar 1.4. Persentase Uji Kelayakan dan Kevalidan Produk Berdasarkan Penilaian Guru Sejarah}

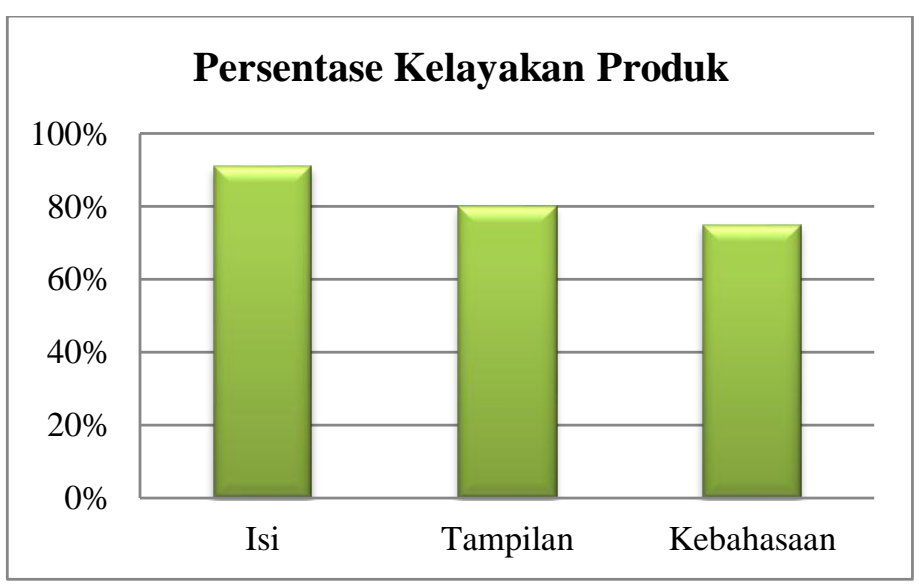

\section{B. Hasil Uji Coba Pada Siswa/ Uji Kelayakan Produk}

Uji coba atau uji kelayakan terhadap lembar kerja peserta didik berbasis emancipatory question sangat diperlukan karena LKPD tersebut berperan sebagai bahan ajar yang dapat digunakan oleh pendidik dan siswa. Untuk itu pada penelitian ini telah dilakukan uji coba atau uji kelayakan pada siswa. Hasil uji coba produk pada kelompok kecil oleh 3 siswa dari kelas XI MIA ${ }^{2}$ diketahui bahwa produk berupa lembar kerja peserta didik (LKPD) berbasis emancipatory question mendapatkan skor penilaian 94 dengan persentase nilai 78\% kategori "layak". Selanjutnya hasil uji coba pemakaian pada kelompok sedang oleh 6 siswa dari kelas XI MIA ${ }^{1}$ diketahui bahwa produk berupa lembar kerja peserta didik (LKPD) berbasis emancipatory question mendapatkan skor penilaian 198 dengan persentase nilai $82,5 \%$ kategori "sangat layak". Berikutnya hasil uji coba pada kelompok besar oleh seluruh siswa kelas XI IIS ${ }^{1}$ diketahui bahwa produk berupa lembar kerja peserta didik (LKPD) berbasis emancipatory question mendapatkan skor penilaian 1074 dengan persentase nilai 89,5\% kategori "sangat layak".

Siswa/i memberikan respon yang positif terhadap bahan ajar lembar kerja peserta didik berbasis emancipatory question, mereka sangat antusias karena mendapat bahan ajar baru serta pengalaman baru dalam belajar sejarah. Selain itu siswa//i juga menyatakan bahwa lembar kerja peserta didik berbasis emancipatory question sangat menarik untuk dijadikan bahan ajar dalam pelajaran sejarah. Di 
kotak saran pada angket respon siswa mereka menuliskan merasa termotivasi untuk belajar sejarah karena selain terdapat infografis dan komik yang dapat mempermudah dalam memahami materi, terdapat juga emancipatory question yang dapat mendorong mereka berpikir kritis dalam pembelajaran sejarah. Hal ini sesuai dengan salah satu tujuan pembelajaran sejarah di tingkat SMA yaitu mengembangkan daya berpikir kritis dan kreatif (Hasan, 2012: 6).

Jika hasil uji coba/uji kelayakan produk pada siswa ditunjukan dalam bentuk diagram batang adalah sebagai berikut :

Gambar 1.5. Hasil Uji Coba/Uji Kelayakan Produk pada Siswa

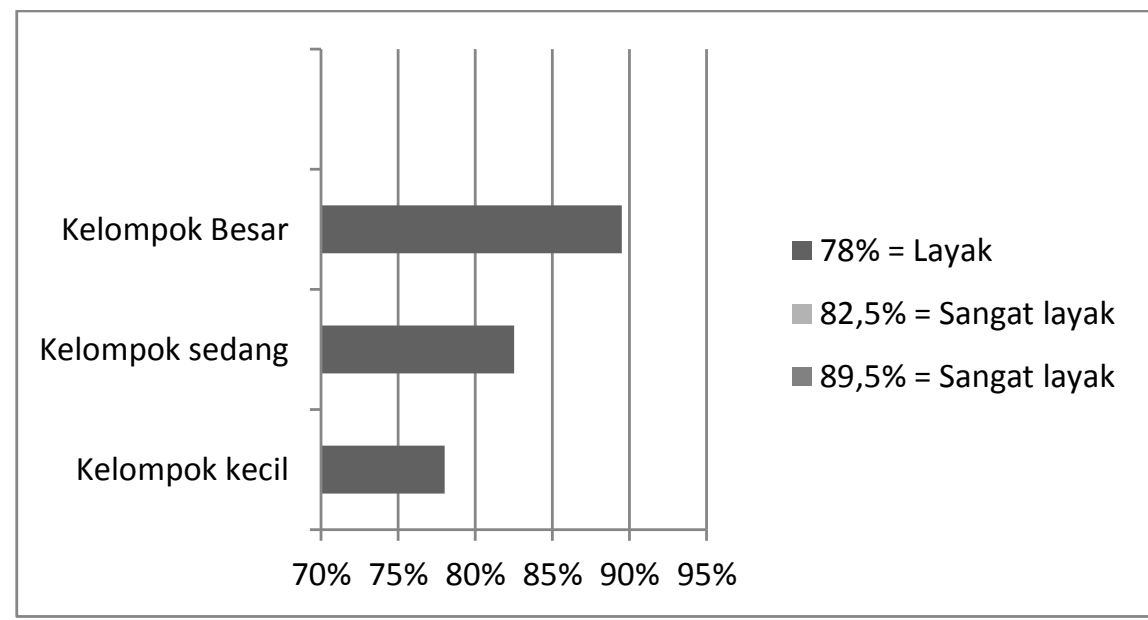

Dengan demikian pengembangan lembar kerja peserta didik (LKPD) mencapai tujuan dari penelitian yaitu melihat respon siswa apakah produk berupa lembar kerja peserta didik (LKPD) berbasis emancipatory question yang dikembangkan tersebut layak digunakan sebagai alat evaluasi pembelajan sejarah.

\section{PENUTUP}

Berdasarkan hasil analisis dan pembahasan dalam penelitian ini dapat dikemukakan simpulan bahwa pengembangan lembar kerja peserta didik (LKPD) berbasis emancipatory question pada materi dampak perkembangan kolonialisme dan imperialisme menggunakan metode Research and Development $(R \& D)$ model Borg and Gall. Pada penelitian ini diselesaikan sampai pada sembilan tahap yang meliputi tahapan potensi dan masalah, pengumpulan informasi, desain produk, 
validasi produk, revisi produk, uji coba produk dan revisi produk. Produk Pengembangan lembar kerja peserta didik (LKPD) berbasis emancipatory question pada materi dampak perkembangan kolonialisme dan imperialisme memperoleh kriteria sangat valid/layak. Hal ini ditunjukkan dengan berdasarkan penilaian $88 \%$ validasi ahli materi, 90\% validasi ahli media pembelajaran sejarah, 90\% validasi ahli evaluasi pembelajaran sejarah, dan $90 \%$ validasi ahli guru sejarah. Sedangkan kelayakan uji coba produk masing-masing berkisar $78 \%$ untuk uji kelompok kecil, $82,5 \%$ untuk uji coba kelompok sedang dan 89,5\% untuk uji coba kelompok besar.

Siswa/i memberikan respon yang positif terhadap bahan ajar lembar kerja peserta didik berbasis emancipatory question, mereka sangat antusias karena mendapat bahan ajar baru serta pengalaman baru dalam belajar sejarah. Selain itu siswa//i juga menyatakan bahwa lembar kerja peserta didik berbasis emancipatory question sangat menarik untuk dijadikan bahan ajar dalam pelajaran sejarah. Di kotak saran pada angket respon siswa mereka menuliskan merasa termotivasi untuk belajar sejarah karena selain terdapat infografis dan komik yang dapat mempermudah dalam memahami materi, terdapat juga emancipatory question yang dapat mendorong mereka berpikir kritis dalam pembelajaran sejarah.

\section{DAFTAR REFERENSI}

Arifin, Johar. (2017). SPSS 24 Untuk Penelitian dan Skripsi. Jakarta: PT. Elex Media Komputindo

Hasan, Said Hamid. (2012). Pendidikan Sejarah Indonesia (Isu dalam Ide dan Pembelajaran). Bandung: Rizqi Press

Pohan, Rizka Nahyuni. (2018). Pengembangan Lembar Kerja Peserta Didik Berbasis Pendekatan Pembelajaran Contextual Teaching and Learning (CTL) PADA Materi Perjuangan Melawan Penjajah Belanda Kelas V di Sekolah Dasar. Skripsi. Fakultas Ilmu Pendidikan. Universitas Negeri Medan

Prastowo, A. (2012). Panduan Kreatif Membuat Bahan Ajar Inovatif. Yogyakarta: Diva Press

Roehati, E. (2009). Pengembangan Lembar Siswa (LKS) (Inovasi Pendidikan). Jilid 10, Nomor 1.

Sani, Ridwan Abdullah. (2014). Inovasi Pembelajaran. Jakarta : Bumi Aksara

Soenarto. (2008). Penelitian Pengembangan Research \& Development (R\&D) Sebagai Upaya Peningkatan Kualitas Pembelajaran. Makalah dipresentasikan pada Sarasehan Metodologi Penelitian, di Program PascaSarjana, UNY.

Sudjana. (2007). Media Pengajaran. Jakarta: Sinar Baru Algesindo 
Sugiyono. (2016). Metode Penelitian Kuantitatif, Kualitatif, $R \& D$. Bandung : Alfabeta.

Sujadi. (2003). Metodologi Penelitian Pendidikan. Jakarta: Rineka Cipta

Sungkono, dkk. (2003). Pengembangan Bahan Ajar. Yogyakarta: FIP UNY

Supriana, Nana. (2007). Konstruksi Pembelajaran Sejarah Kritis. Makalah dipresentasikan pada Seminar Pembelajaran Sejarah, Mei 2007, Bandung.

Surapranata, Sumarna. (2006). Analisis, Validitas, Reliabilitas dan Interpretasi Hasil Tes Implementasi Kurikulum. Bandung : Remaja Rosdakarya.

Suryani, Nunuk.,Achmad Setiawan dan Aditin Putria. (2018). Media Pembelajaran inovatif dan Pengembangannya. Bandung: Remaja Rosdakarya

Tanjung, Flores dan Al Haris Nasution. (2015). Telaah Kurikulum dan Pembelajaran Sejarah. Medan: Jurusan Pendidikan Sejarah Fakultas Ilmu Sosial Universitas Negeri Medan

Trianto. (2009). Model Pembelajaran Terpadu. Jakarta: Bumi Aksara

Surbakti, Aulia. (2014). Penerapan Emancipatory Question Habermas Untuk Meningkatkan Kesadaran Sejarah Siswa (Penelitian Tindakan Kelas Pada sPembelajaran Sejarahdi Kelas XI IPS SMA Bina Bangsa Palembang). Bandung : Jurnal Pendidikan Ilmu Sosial. Vol. 23, No.1:35-43.

Education, zenius. (2014). Daftar Pelajaran yang Tidak Disukai Siswa. (https://www.zenius.net/diakses pada 9 Juni 2019)

Matanasi, Petrik. (2016). Mengapa Pelajaran Sejarah Tak Disukai. (https://tirto.id/mengapa-pelajaran-sejarah-tak-disukai-bUc2 diakses pada 9 Juni 2019)

Pemerintah Indonesia. (2005). Undang-Undang Republik Indonesia Nomor 14 Tahun 2005 Tentang Guru dan Dosen. Lembaran RI Tahun 2005 No.14. Jakarta : Sekretariat Negara. (http://luk.staff.ugm.ac.id/atur/UU142005GuruDosen.pdf diakses pada 9 Juni 2019) 